\title{
Inhibition of HCV by the serpin antithrombin III
}

\author{
Mohammed Asmal ${ }^{1,2^{*}}$, Michael Seaman ${ }^{1,2}$, Wenyu Lin ${ }^{2,3}$, Raymond T Chung ${ }^{2,3}$, Norman L Letvin ${ }^{1,2^{\wedge}}$ \\ and Ralf Geiben-Lynn ${ }^{1,2}$
}

\begin{abstract}
Background: Although there have been dramatic strides made recently in the treatment of chronic hepatitis C virus infection, interferon-a based therapy remains challenging for certain populations, including those with unfavorable IL28B genotypes, psychiatric co-morbidity, HIV co-infection, and decompensated liver disease. We have recently shown that ATIII, a serine protease inhibitor (serpin), has broad antiviral properties.

Results: We now show that ATIII is capable of inhibiting HCV in the OR6 replicon model at micromolar concentrations. At a mechanistic level using gene-expression arrays, we found that ATIII treatment down-regulated multiple host cell signal transduction factors involved in the pathogenesis of cirrhosis and hepatocellular carcinoma, including Jun, Myc and BMP2. Using a protein interactive network analysis we found that changes in gene-expression caused by ATIII were dependent on three nodes previously implicated in HCV disease progression or HCV replication: NFKB, P38 MAPK, and ERK1/2.
\end{abstract}

Conclusions: Our findings suggest that ATIII stimulates a novel innate antiviral host cell defense different from current treatment options.

Keywords: Antithrombin III, Hepatitis C virus, OR6 replicon cells, NFKB, P38 MAPK, ERK1/2

\section{Background}

Antiviral treatment of hepatitis C virus (HCV) is aimed at persistent eradication of the virus, as measured in sustained virological response (SVR). SVR rates are high with current treatment options, a combination of peginterferon-apha (IFN- $\alpha)$-ribavirin and direct-acting antiviral agent (DAA) but HCV patients infected with HIV and/or other co-morbidities might benefit less from the new treatment options [1].

$\mathrm{HCV}$ infection is currently one of the most clinically relevant co-morbidities in the HIV population; it affects $15-30 \%$ of the 1 million HIV-positive patients in the US [2]. Furthermore, progression to end-stage liver disease occurs six times faster in co-infected patients [3-6], with decompensated cirrhosis being one of the primary causes of hospitalization and death in this population [4,6-8]. Treatment of HCV infection in HIV-positive patients has a lower success rate [9-13] and an increased risk of hepatotoxicity from antiretroviral drugs compared to HIV-

\footnotetext{
*Correspondence: masmal@partners.org

Deceased

'Division of Viral Pathogenesis, BIDMC, Boston, MA 02215, USA

${ }^{2}$ Harvard Medical School, Boston, MA 02215, USA

Full list of author information is available at the end of the article
}

negative patients [14-16]. Because of an increased risk of life-threatening complications during peg-IFN- $\alpha$-ribavirin therapy, patients with hepatic decompensation are not typically candidates for this therapy unless easy access to orthotopic liver transplantation is available $[17,18]$. Furthermore, since the antiviral activity of IFN- $\alpha$ is mediated, at least in part, through the cytokine network, immunological abnormalities, such as those that often result from HIV infection, reduce IFN- $\alpha$ efficacy. This loss of efficacy has the result of higher treatment failure in $\mathrm{HIV} / \mathrm{HCV}$ coinfected patients when compared to $\mathrm{HCV}$ monoinfected patients [19-22].

The effective treatment of HIV in persons with advanced cirrhosis may be challenging due to cirrhosisinduced alterations in the hepatic metabolism of antiretroviral drugs and the potential for increased risk of drug-induced liver injury. To prevent possible liver toxicity, drug doses may be reduced and certain otherwise preferred drugs may be avoided [23,24]. Reducing antiretroviral doses and hence plasma concentrations, however, may also lower the barrier to the emergence of drug-resistant HIV. Thus, effective therapy to eliminate HCV is necessary to optimize therapy for HIV.
C Biomed Central

(c) 2012 Asmal et al.; licensee BioMed Central Ltd. This is an Open Access article distributed under the terms of the Creative Commons Attribution License (http://creativecommons.org/licenses/by/2.0), which permits unrestricted use, distribution, and reproduction in any medium, provided the original work is properly cited. 
We are investigating here antithrombin III (ATIII), a member of the serine protease inhibitor protein family (serpins), as its anti-inflammatory and anticoagulant activities were found to decrease liver damage [25]. Serpins participate in the early innate immune response to viral infection [26] and they simultaneously possess broadspectrum anti-viral and anti-inflammatory capabilities. In the case of HIV infection, serpins reportedly interfere with viral replication at both the entry and the reverse transcription stages [27-30]. In particular, the serpins alpha-1 anti-trypsin, the secretory leukocyte protease inhibitor and ATIII have significant in vitro ability to inhibit HIV-1, with the latter, ATIII, being the most potent [29-34].

In $\mathrm{HCV}$ infections with co-morbidities new drugs with different mechanisms of action other than the DAAs are urgently needed. We hypothesized that the broad immunomodulatory and anti-viral properties of ATIII might extend to other chronic viral infections due to a different mechanism of action, in particular, since a serpin receptor, the LDL receptor-related protein 1 (LRP1), is highly expressed on hepatocytes [34] and was found to block HCV infection [35].

Therefore, we undertook an investigation of whether ATIII has the potential to inhibit HCV replication in vitro. We used gene-arrays to probe the molecular mechanisms underlying ATII's immunomodulatory and antiviral properties, and uncover the signal transduction pathways that result in inhibition of viral replication.

\section{Results}

\section{ATIII treatment augments the inhibition of HCV} replication by IFN- $a$

IFN- $\alpha$ is currently part of the standard therapy for chronic HCV infection, in addition to ribavirin and an NS3-4A protease inhibitor. In certain patient subpopulations, this regimen is not always effective or is poorly tolerated. We have previously reported that the serpin ATIII has potent anti-viral activity against HIV [33,34]. We sought to determine whether ATIII might also have activity against $\mathrm{HCV}$ since serpin receptors are highly expressed on hepatocytes [36]. We employed the OR6 replicon system [37] expressing full-length genotype $1 \mathrm{~b}$ virus to assess whether ATIII is capable of inhibiting HCV [38,39]. Although heparin activation augments the anti-HIV activity of ATIII we used unmodified ATIII because heparin activation also increases the off-target effects of ATIII on thrombin. Unmodified ATIII has a demonstrated favorable toxicity profile and has been used in humans for more than 20 years.

We initially explored the effect of ATIII monotherapy on HCV replication. We treated OR6 replicon cells with 7, 17 and $58 \mu \mathrm{M}$ of ATIII for $48 \mathrm{~h}$. We had previously demonstrated that these concentrations effectively inhibited HIV replication in vitro [40]. We quantified viral inhibition as the percentage of residual luciferase activity compared to a vehicle treated control. We observed that ATIII monotherapy inhibited HCV replication in the replicon system in a dose dependent manner, with the lowest dose of $7 \mu \mathrm{M}$ inhibiting virus $70.2 \% \pm 8.8 \%$ $(\mathrm{p}<0.001, \mathrm{n}=6)$ (Figure 1A).

For comparison, we assessed the ability of IFN- $\alpha 2$ monotherapy to inhibit the replicon. We tested doses of 4 and 16 IU IFN- $\alpha 2$, and found $71.4 \pm 10.1 \%$ and 84.4 $\pm 8.4 \%$ inhibition of $\mathrm{HCV}$, respectively. These results are similar to what has been reported previously [41]. We next sought to determine whether ATIII and IFN- $\alpha$ might have an additive effect on $\mathrm{HCV}$ replication. We treated replicon cells with 7, 17 and $58 \mu \mathrm{M}$ ATIII and with 4 and $16 \mathrm{IU} / \mathrm{ml}$ IFN- $\alpha 2$ (Figure 1B/C). We observed an additive effect, as treatment with ATIII significantly decreased HCV replication compared to IFN$\alpha 2$ monotherapy (P-value of between $<0.05$ and $<0.01$ ).

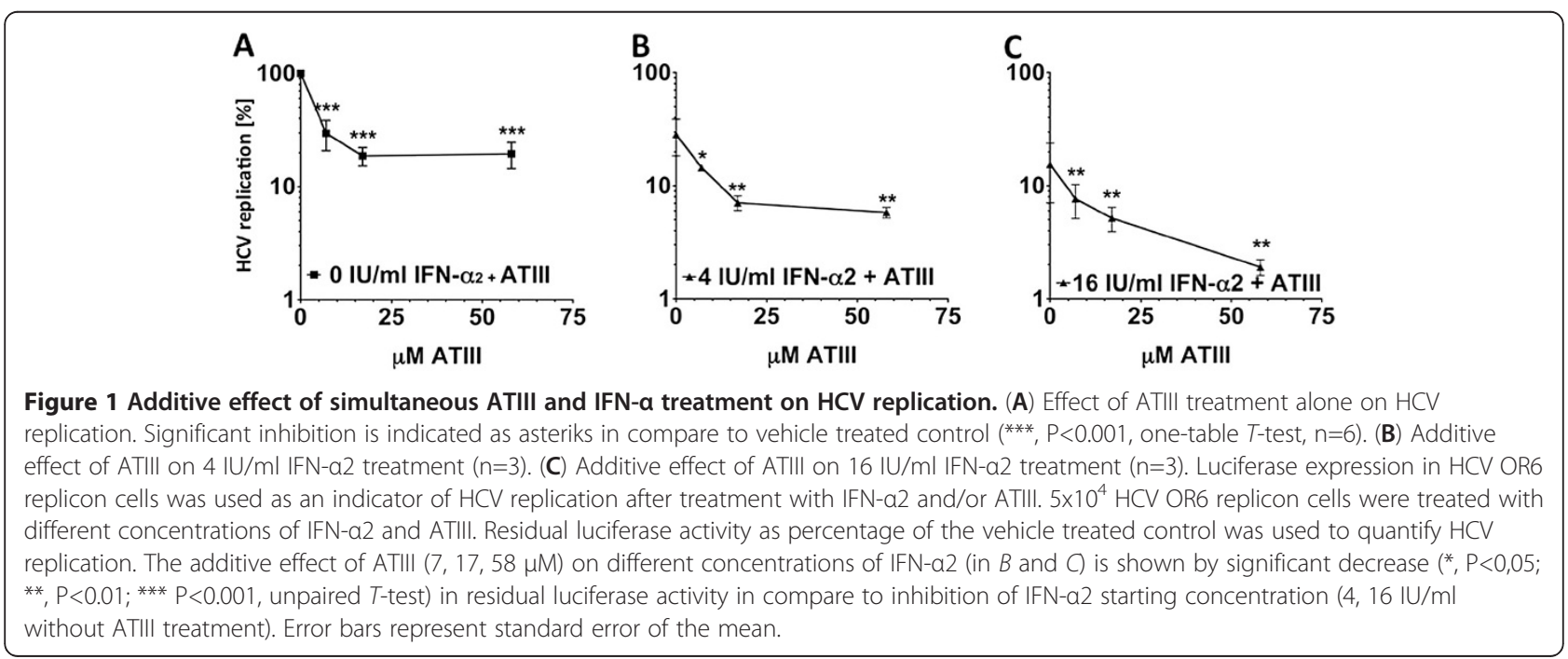


This additive effect was already observed at the lowest dose $(7 \mu \mathrm{M})$ of ATIII tested (Figure 1). We performed similar experiments using IFN- $\alpha 5$, a different subtype of IFN- $\alpha$, and confirmed the additive effects of ATIII observed with IFN- $\alpha 2$ (data not shown).

To exclude the possibility that the antiviral effect of ATIII was due to a cytotoxic effect, we assayed for cytotoxicity using Neutral Red and Trypan Blue exclusion staining at the indicated concentrations of drugs. Neither ATIII alone or in combination with IFN- $\alpha 2$ or IFN- $\alpha 5$ showed a cytotoxic effect (data not shown).

\section{ATIII-induced alterations in gene expression in non- replicon cells}

To assess the effect of ATIII treatment on host cell gene expression in the absence of $\mathrm{HCV}$ protein expression, we treated Huh7.5. non-replicon cells with the highest concentration of ATIII that would be used in the subsequent gene array experiments: $24 \mathrm{U} / \mathrm{ml}(58 \mu \mathrm{M})$, which is 24-fold the physiologic concentration. We found no significant alterations in expression of genes in the array following ATIII treatment of the non-OR6 replicon cells, demonstrating that, at these concentrations and in the absence of HCV replication, ATIII has no significant effect on expression of our transcriptional pathways of interest. Using Trypan Blue exclusion staining we also found no drug-related cytotoxicity at the concentrations used (data not shown).

\section{$\mathrm{HCV}$-induced alterations of hepatocyte gene expression}

To assess the effect of HCV replication on hepatocyte physiology we compared the transcriptional profile of HCV replicon cells to that of Huh7.5 non-replicon cells using the Transduction Pathfinder RT2 Profiler PCR Assay. Initially, experiments were performed in the absence of exogenous ATIII. We observed substantial differences in the transcription of multiple genes involved in the innate host cell response between cells expressing and not-expressing HCV (Tab. I). Many of these $\mathrm{HCV}$-induced changes have been previously described elsewhere [42-49] confirming the validity of our system. The gene with the greatest increase in expression was Matrix Metallopeptidase 10 (MMP10) (49fold, $\mathrm{P}=0.006)$, a key mediator in the Jak-Stat pathway and part of the inflammatory response of the host cell against $\mathrm{HCV}$. Additional effects of $\mathrm{HCV}$ on host gene expression include activation of p53 and TGF- $\beta$ pathways: we found a 3 -fold $(\mathrm{P}=0.03)$ increase of Cyclindependent kinase inhibitor (CDKN) $1 \mathrm{~A}$ and a 10 -fold $(P=0.005)$ increase of CDKN2B. Other observations from this study that are consistent with previously described associations with $\mathrm{HCV}$ include findings of a 9-fold $(P=0.04)$ increase of Bone morphogenetic protein 4 (BMP4), part of the hedgehog pathway, and a 4-fold $(\mathrm{P}=0.03)$ increase in Heat Shock Protein (HSP) 90AA2, part of the cellular stress response.

\section{Effect of ATIII on HCV-induced changes in gene expression}

We subsequently sought to determine if ATIII might modulate the effects of $\mathrm{HCV}$ on host gene expression. We treated replicon cells with $7 \mu \mathrm{M}$ ATIII, a concentration at which inhibition of $\mathrm{HCV}$ replication was observed, and compared gene expression to untreated replicon cells (Table 1). None of the genes affected by HCV expression appeared to be substantially affected by ATIII treatment at this lowest dose.

At higher concentrations of ATIII, we found only a modest effect on $\mathrm{HCV}$-induced transcriptional changes (data not shown). There was no ATIII dose-dependent

Table 1 Determination of ATIII treatment effect on gene expression in the context of HCV

\begin{tabular}{|c|c|c|c|c|c|}
\hline \multirow[t]{2}{*}{ Gene } & \multirow[t]{2}{*}{ Symbol } & \multicolumn{2}{|c|}{$\begin{array}{l}\text { Replicon/Non-replicon } \\
\text { Gene expression }\end{array}$} & \multicolumn{2}{|c|}{$\begin{array}{l}\text { Replicon/Replicon+7 } \mu \mathrm{M} \\
\text { ATIII Gene expression }\end{array}$} \\
\hline & & Fold change & P-value & Fold change & P-value \\
\hline Bone morphogenetic protein 4 & BMP4 & 9.15 & 0.04 & -1.68 & 0.09 \\
\hline Cyclin-dependent kinase inhibitor $1 \mathrm{~A}$ & CDKN1A & 2.61 & 0.03 & -1.64 & 0.1 \\
\hline Cyclin-dependent kinase inhibitor 2B & CDKN2B & 10.98 & 0.005 & -1.59 & 0.1 \\
\hline Cytochrome P450, family 19, subfamily A, polypeptide 1 & CYP19A1 & 5.70 & 0.002 & -1.73 & 0.01 \\
\hline Fatty acid synthase & FASN & 4.01 & 0.01 & -2.87 & 0.9 \\
\hline Heat shock 27kDa protein 1 & HSPB1 & 2.82 & 0.001 & -1.21 & 0.6 \\
\hline Heat shock protein 90kDa alpha class A member 2 & HSP90AA2 & 4.01 & 0.03 & -1.14 & 0.6 \\
\hline Interleukin 4 receptor & IL4R & 4.76 & 0.01 & -1.79 & 0.04 \\
\hline Matrix metallopeptidase 10 & MMP10 & 49.29 & 0.006 & -2.19 & 0.3 \\
\hline Ornithine decarboxylase 1 & ODC1 & 4.49 & 0.01 & 1.35 & 0.4 \\
\hline Retinol binding protein 1 & RBP1 & 2.66 & 0.045 & -1.59 & 0.2 \\
\hline WNT1 inducible signaling pathway protein 1 & WISP1 & 6.32 & 0.008 & -1.16 & 0.6 \\
\hline
\end{tabular}


effect on expression of any of the genes in Table I. These results suggest that the mechanism by which ATIII inhibits $\mathrm{HCV}$ within $48 \mathrm{~h}$ may not involve modulation of the genes influenced by HCV infection.

\section{ATIII-induced alterations in replicon cell gene expression}

$\mathrm{HCV}$ infection often leads to chronic hepatitis, cirrhosis, and occasionally to hepatocellular carcinoma [50]. This progression in liver pathology is associated with increased expression in hepatocytes of the transcription factors JUN and MYC, which may play crucial roles in oncogenesis [51,52]. In order to investigate the influence of ATIII on pathways important for HCV disease progression we employed the Transduction Pathfinder RT2 Profiler PCR Assay to quantify the expression of 84 key genes belonging to 18 different regulatory pathways in the presence of different concentrations of ATIII.

To investigate whether the therapeutic use of ATIII might have an influence on gene-expression in OR6 replicon cells, we treated these cells with supra-physiologic concentration of ATIII: 2.4-fold (7 $\mu \mathrm{M})$, 7-fold (17 $\mu \mathrm{M})$ and 24-fold $(58 \mu \mathrm{M})$ blood concentrations. We used supra-physiologic doses of ATIII in part because ATIII is known to accumulate in the liver - a fact which may be of therapeutic advantage.

Treatment of replicon cells with these doses of ATIIII altered expression by more than 5-fold in a group of genes when compared to vehicle treated controls (Figure 2). Interestingly, genes that were most significantly affected were all down-regulated. Among those genes found to be down-regulated following ATIII treatment were JUN and MYC, which are known to be important factors in the pathogenesis of HCV-related hepatocellular carcinoma. We found that these genes were down-regulated in a dose dependent manner, up to 931-fold for JUN ( $\mathrm{P}=0.0002)$, and up to 45-fold for MYC $(\mathrm{P}=0.0007)$ at $58 \mu \mathrm{M}$.

The next largest decrease in gene expression, up to 346fold ( $\mathrm{P}=0.009$ at $58 \mu \mathrm{M})$, was observed for the transcription factor CAAT/enhancer binding protein (CEBPB), a protein regulated by insulin. Another gene downstream of insulin Hexokinase 2 (HK2), was down-regulated up to 14-fold ( $\mathrm{P}=0.0039)$. Growth arrest and DNA-damageinducible protein (GADD45A), a gene in the p53 pathway, was down-regulated 35 -fold at $58 \mu \mathrm{M}(\mathrm{P}=0.0023)$. Bone morphogenetic protein 2 (BMP2), a gene of the Hedgehog pathway, was down-regulated 13 -fold $(\mathrm{P}=0.03)$ at $58 \mu \mathrm{M}$. B-cell CLL/lymphoma2-like 1 (BCL2L), a transcript belonging to the Jak/Src pathway, exhibited an approximately 10-fold decrease in expression (Figure 2). Downregulation of these genes was specific to ATIII treated OR6 cells with ongoing HCV replication, and was not observed in the untreated OR6 replicon, nor in the ATIII-

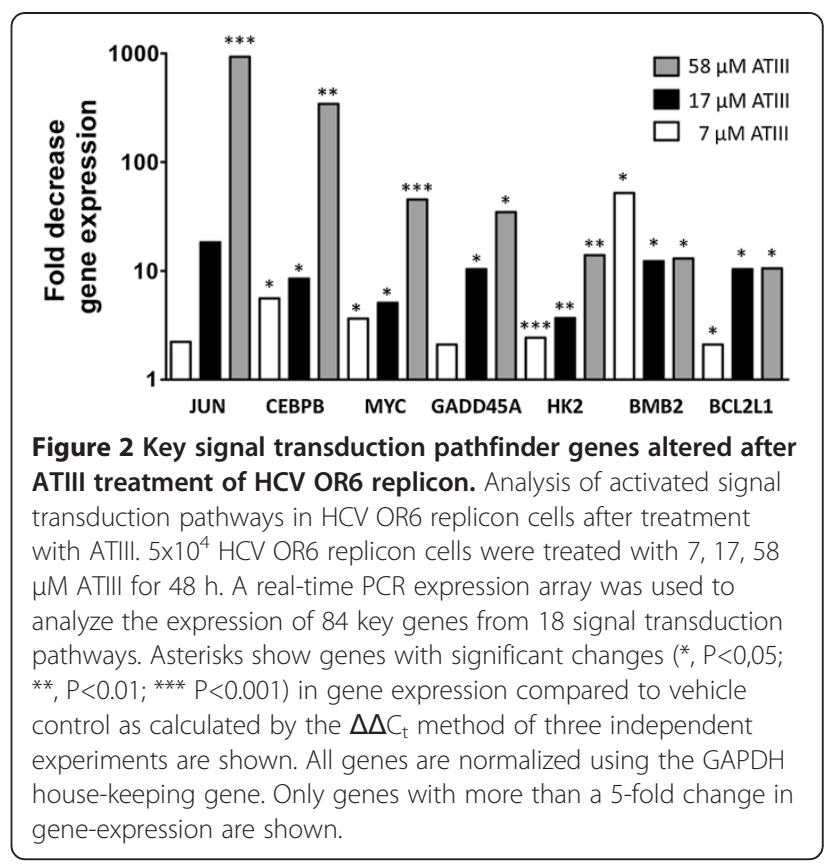

treated Huh7.5 controls suggesting that ATIII induces a specific anti-viral gene program.

\section{Changes in gene expression when ATIII is used in combination with IFN-a}

Our data indicate that both IFN- $\alpha$ and ATIII stimulate the host innate antiviral response. We sought to determine whether these proteins engaged redundant cellular pathways, or had non-overlapping mechanisms of action. We applied IFN- $\alpha 2$ in isolation, to measure the gene expression alterations attributable to this drug. The gene expression profile induced by IFN- $\alpha$ monotherapy that we observed was consistent with previous reports $[53,54]$. At $4 \mathrm{IU} / \mathrm{ml}$, we found Interferon regulatory factor 1 (IRF-1) up-regulated 2-fold. We also identified a set of inflammatory genes that were down-regulated: Colony stimulating factor 2 (CSF2) (inhibited 11.5-fold, $\mathrm{P}=0.01$ ), IL-1 $\alpha$ (inhibited 4-fold, $\mathrm{P}=0.02$ ), MMP7 (inhibited 6-fold, $\mathrm{P}=0.04$ ), MMP10 (inhibited 3-fold), Nitric oxide synthase 2A (NOS2A) (inhibited 9-fold, $\mathrm{P}=0.009$ ), and Prostaglandin-endoperoxide synthase (PTGS2) (5fold, $\mathrm{P}=0.01$ ) (Figure 3).

When IFN- $\alpha$ was administered in combination with ATIII, additional genes were significantly altered, potentially explaining the additive antiviral effect of ATIII when added to IFN- $\alpha$ treatment. The most substantially down-regulated gene was BMP2, belonging to the Hedgehog pathway, which was decreased by 37 -fold $(\mathrm{P}=0.04)$. JUN and PTGS2 both belonging to the Phospholipase $\mathrm{C}$ pathway were 14-fold $(\mathrm{P}=0.08)$ and 9fold $(\mathrm{P}=0.02)$ down-regulated. $\mathrm{CEBPB}$ of the insulin pathway was 8-fold down-regulated (Figure 3). 


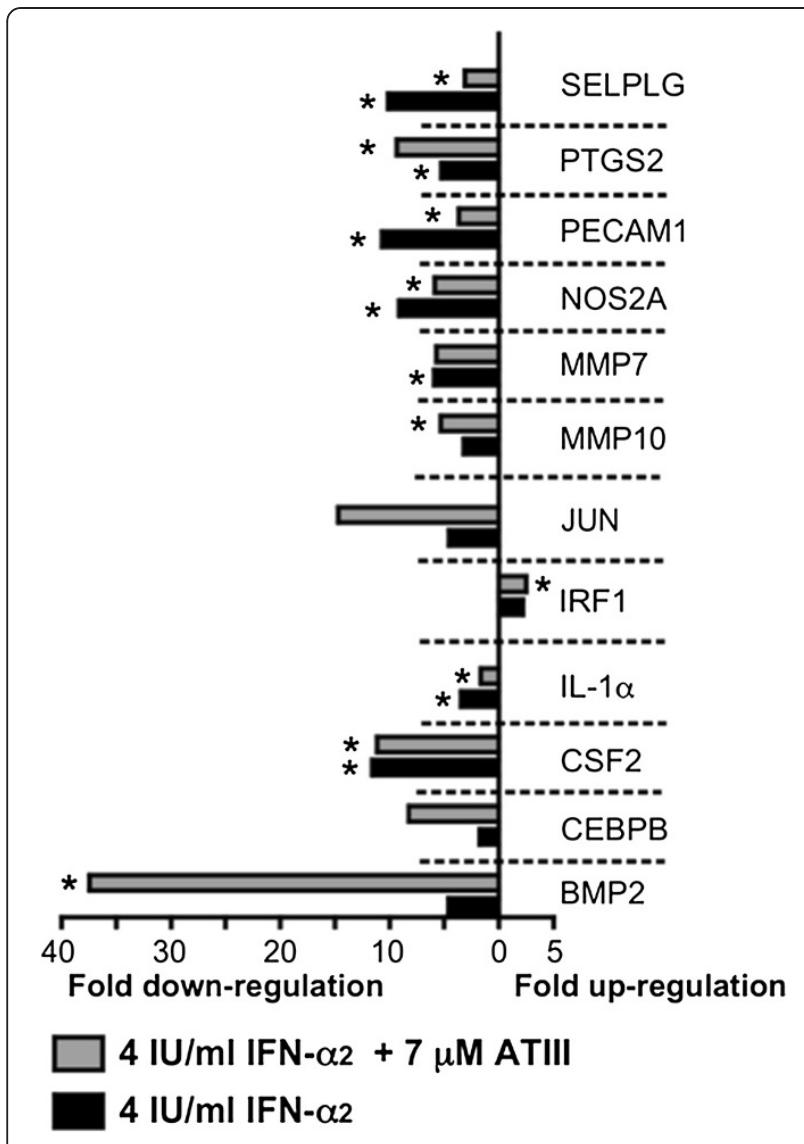

Figure 3 Down-regulation of key signal transduction pathway genes in HCV OR6 replicon after treatment with IFN- $\alpha$ and ATIII. $5 \times 10^{4} \mathrm{HCV}$ OR6 replicon cells were treated with $7 \mu \mathrm{M}$ ATIII/ml

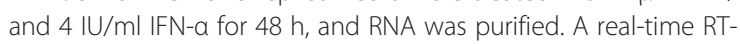
PCR expression array was used to analyze the expression of 84 key genes from 18 signal transduction pathways. Genes with significant changes $\left({ }^{*}, \mathrm{P}<0.05\right)$, in gene expression compared to vehicle control as calculated by the $\Delta \Delta C_{t}$ method of three independent

experiments are shown. All genes are normalized using the GAPDH house-keeping gene. Only genes with more than a 2 -fold change in gene-expression are shown.

We repeated these experiments using IFN- $\alpha 5$, to exclude the possibility that our results may have been idiosyncratic to IFN- $\alpha 2$. We observed the same gene expression pattern with IFN- $\alpha 5$ treatment, with or without ATIII treatment (data not shown).

\section{Network analysis of ATIII-induced interactomes in OR6 replicon cells}

To gain further insight into the mechanism of action of ATIII in reducing HCV replication, we performed a biologic network analysis of ATIII treated OR6 replicons. This analysis method complements data generated from our gene arrays by facilitating the recognition of hierarchical gene clusters that might intersect with $\mathrm{HCV}$ replication. This software-supported interactome analysis is based on a vast library of gene interactions known to regulate certain pathways and allows to identify pathways effected by a drug.

We used genes which we had observed to be significantly up-regulated by HCV replication (Table 1) to generate interactomes describing host cell transduction pathways activated by $\mathrm{HCV}$. We identified nodules regulated by ERKs, AKT, PI3K, RAS, NFkB, P38, P38 MAPK and MAPK as all being activated by $\mathrm{HCV}$ infection (Figure 4A). We then assessed the influence of treatment with the high dose $(58 \mu \mathrm{M})$ of ATIII on gene expression to determine which of these $\mathrm{HCV}$ nodules were affected by gene expression changes downstream of ATIII. We found that ATIII interacted with two independent networks that were also modulated by $\mathrm{HCV}$. The highest scoring network was mostly dependent on the ERKs (Figure 4B), and the second highest scoring network interfered with NFKB and P38 MAPK (Figure 4C). These results suggested that despite our observation that ATIII and $\mathrm{HCV}$ alter the expression of different sets of individual genes, transcriptional programs activated by ATIII may interfere with 3 out of the 6 nodules activated by HCV. We hypothesize that this might be significant enough to counteract some of the pathologic effects of HCV.

We have demonstrated additive activity of IFN- $\alpha$ and ATIII in inhibiting HCV. We thus next sought to determine whether they might exhibit overlapping effects on the $\mathrm{HCV}$ interactome. We compared the effect of IFN$\alpha /$ low ATIII dose therapy to that of IFN- $\alpha$ alone on $\mathrm{HCV}$ induced nodules. Treatment with $4 \mathrm{IU} / \mathrm{ml}$ IFN- $\alpha$ alone altered three HCV induced nodules: P38 MAPK, MAPK and NFKB (Figure 4D). The addition of low dose ATIII did not alter the number of nodules affected, but did increase the IRF1 response (Figure 4E) which is known to be responsible for some of the HCV inhibition and might be the reason for the additive effect on IFN- $\alpha$ treatment.

\section{Discussion}

The cornerstone of effective therapy for chronic hepatitis $C$ infection has been IFN- $\alpha$, a critical mediator in the innate immune response to viral infection. Even with the advent of small molecule direct inhibitors of viral enzymatic activity, IFN- $\alpha$ remains important for attaining sustained virologic response, perhaps because of the need to engage host antiviral programs to completely eradicate viral reservoirs. However, interferon-based therapy is not without its shortcomings, including poor tolerability or poor efficacy in certain patient populations.

We now demonstrate that a novel activator of host innate antiviral responses, ATIII, may give insight into adjunctive therapies for $\mathrm{HCV}$ that might augment or even replace IFN- $\alpha$ in cases where there are co-morbidities or genetic factors that preclude the use of IFN- $\alpha$. There is 


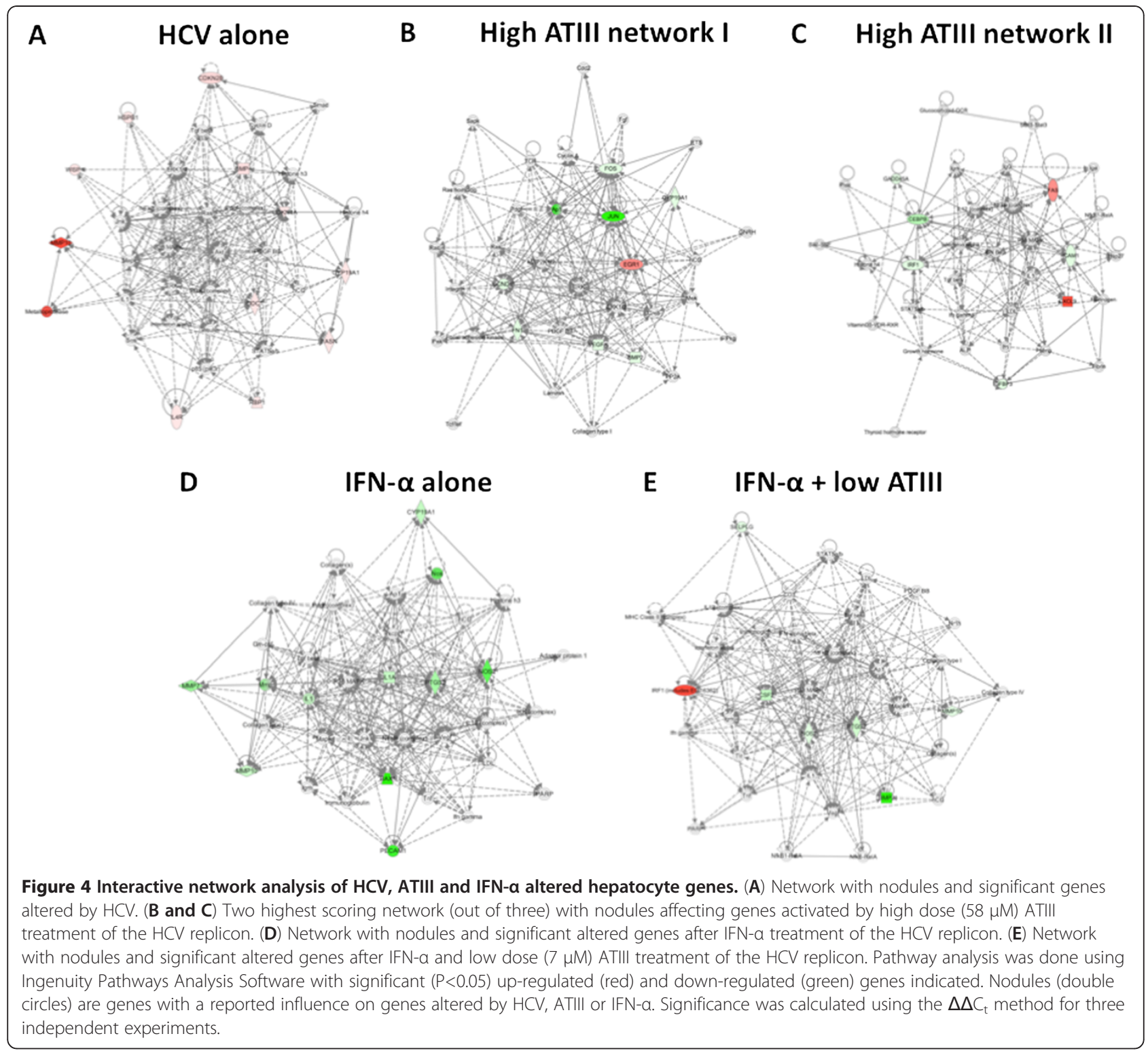

circumstantial evidence that ATIII may play a role in the pathogenesis of $\mathrm{HCV}$ infection: low plasma concentrations of ATIII have previously been correlated with progression to chronic hepatitis and cirrhosis [55]. Furthermore, there is a high density of serpin receptors on hepatocytes, suggesting that serpins may have localized effects on hepatic innate immunity [56].

We used the OR6 replicon to probe how ATIII might influence $\mathrm{HCV}$ pathogenesis. We demonstrated that ATIII inhibited HCV replication at micromolar concentrations. While this inhibition was not as potent as that of either IFN- $\alpha$ or fluvastatin [41] it was many-fold greater than that of ribavirin [57].

We next investigated the mechanism of ATIII's anti$\mathrm{HCV}$ activity. After more than 20 years of research, the mechanism of action of IFN- $\alpha$ in inhibiting $\mathrm{HCV}$ has only recently been determined. HCV cell-based expression models, as the one used in this study, were used to demonstrate that IFN- $\alpha$-induced signal transduction through the Jak/STAT pathway was necessary for HCV inhibition [45]. To elucidate the mechanism(s) through which serpins activate the host defense system, we employed the OR6 replicon system, and analyzed changes in geneexpression patterns of 84 key genes representative of 18 different signal transduction pathways. We found that ATIII treatment down-regulated JUN expression. It has previously been shown that the JNK inhibitor, SP600125, interferes with the oncogenic potential of $\mathrm{HCV}$ nonstructural protein 3 [58]. In addition, we found that ATIII treatment reduced induction of the transcription factor MYC, expression of which has been associated with progression of liver disease to chronic hepatitis, cirrhosis, and 
hepatocellular carcinoma [52,59]. ATIII treatment also reduced CEBPB, a transcription factor of the CCAAT/ enhancer-binding protein class. These transcription factor proteins have been shown to be important for $\mathrm{HCV}$ inhibition: the CCAAT/enhancer-binding proteinhomologous protein (CHOP) is activated by HCV envelope protein and is associated with disease progression [60]. The mechanism of action of this protein class is not fully understood, but $\mathrm{CHOP}$ can sensitize cells to apoptosis by down-regulation of BCL-2 expression, depletion of cellular glutathione, and exaggerated production of reactive oxygen species [61].

Our data also identified a substantial down-regulation of BMP2, a protein that regulates hepcidin [62]. Hepcidin is critical for iron homeostasis and is also a critical host cofactor involved in promoting $\mathrm{HCV}$ replication [63]. Chronic HCV infection has been found to be associated with increased serum iron and transferrin saturation as well as hepatic iron accumulation; moreover, hepatic hepcidin mRNA expression is increased in patients with chronic HCV infection [64]. Hepcidin transcription is stimulated by iron overload as well as by inflammation through IL-6 [65], which is elevated in patients with chronic HCV. The identification of hepcidin as a HCV replication cofactor suggests a molecular basis for the well-known clinical association between chronic HCV infection and dysregulation of iron homeostasis. Moreover, it is possible that the upregulation of hepcidin transcription by IL- 6 potentially creates a positive feedback loop between chronic inflammation and HCV replication. Together, these findings suggest that ATIII therapy may reduce the pathogenic impact of HCV infection.

Thus, our data indicate that ATIII targets several genes that are known to promote both liver disease and $\mathrm{HCV}$ replication. ATIII treatment may therefore alter the expression of these genes and act to simultaneously slow both HCV replication and ultimately liver degeneration. ATIII's effect on gene-expression was also observed when replicon cells were co-treated with low concentrations of IFN- $\alpha$. It was during this dual drug treatment that gene expression of BMP2, CEBPB, and JUN were most dramatically down-regulated.

Protein interactive network analysis demonstrated that the genes that were altered by ATIII treatment were dependent on three nodes: NFKB, P38 MAPK and the ERKs. All of these nodes have been described previously as having a role in $\mathrm{HCV}$ replication and HCV-related liver disease [47,66-69] confirming ATIII's potential to limit HCV's destruction of the liver. These nodules are also affected in ATIII-mediated inhibition of HIV [40].

Although our replicon model can facilitate identification of substances that affect either viral genomic replication or host cell factors involved in viral genomic replication, it cannot be used to identify substances that alter other stages of the viral life cycle. Therefore, future studies using fully infectious, cell-culture-adapted HCV strains will be required to study other aspects of the HCV life cycle, such as viral entry, uncoating, viron assembly and secretion. Our data identified several genes altered by ATIII that were previously shown to be correlated with $\mathrm{HCV}$ disease outcome. This might explain the additive therapeutic effect when ATIII was used in combination with IFN- $\alpha$. We further found that ATIII's mechanism of action is most likely multi-faceted, warranting further research into each distinct signaling pathway.

\section{Material and methods \\ Cell culture}

OR6 replicon cells were a gift from Dr. Nobuyuki Kato (Okayama University, Japan) and were propagated in Dulbecco's Modified Eagle's medium (DMEM) containing $10 \%$ fetal bovine serum (FBS) supplemented with $1 \%$ penicillin-streptomycin, and $500 \mu \mathrm{g} / \mathrm{ml}$ Geneticin (Invitrogen Corp., Carlsbad, CA). Cells were cultured in a $37^{\circ} \mathrm{C}, 5 \% \mathrm{CO} 2$-humidified incubator for all experiments. To decrease day-to-day variability in the assay, a large homogenous population of subconfluent cells was passaged so that a similar lot of cells could be used throughout the assay.

\section{Protein reagents}

Clinical grade human ATIII (Talecris, Durham, NC) had a concentration of $6 \mathrm{U} / \mathrm{mg}$ and a purity $>98 \%$. For ATIII drug combination experiments, recombinant human IFN$\alpha 2$ and IFN- $\alpha 5$ (PBL Interferon Source, Piscataway, NJ) was used, which had a concentration of $2.38 \times 10^{8}$ and $2.33 \times 10^{8}$ units $/ \mathrm{mg}$, respectively, and a purity of $>98 \%$.

\section{Determination of inhibitory potency}

$\mathrm{HCV}$ replication inhibition was determined as the percentage of luciferase activity retained by the OR6 replicon after ATIII treatment, compared to a vehicle-treated control [37]. Luciferase activity was measured using the Renilla Luciferase Assay System (Promega, Madison, WI) at $1 \mathrm{sec}$. intervals using the 1420 Multilabel Counter Victor 3 (PerkinElmer, Waltham, MA). Cell viability was assessed using Neutral Red staining and Tryphan Blue exclusion staining.

\section{Signal transduction pathway profiling}

OR6 replicon cells were harvested after $48 \mathrm{~h}$ of ATIII and/or IFN- $\alpha$ treatment and total RNA was recovered using the RNeasy Kit (Qiagen) with an on-column DNAse digest (Qiagen) according to the manufacturer's protocol. Approximately 100 ng RNA was used for cDNA synthesis using the SuperArray $\mathrm{RT}^{2}$ First Strand Kit (SABiosciences, Frederick, MD, cat. no. C-03). cDNA 
was used for the $\mathrm{RT}^{2}$ Profiler PCR Array Human Signal Transduction PathwayFinder (SABiosciences, cat. no. PAHS-014A). The genes that were investigated can be found at http://www.sabiosciences.com/rt_pcr_product/ HTML/PAHS-014A.html. Three arrays of three independent experiments were performed for each treatment condition. Relative levels of transcription were determined by using the $\Delta \mathrm{C}_{\mathrm{t}}$ values for each gene obtained by subtracting the mean threshold cycle $\left(\mathrm{C}_{\mathrm{t}}\right)$ of the GAPDH housekeeping gene from the $C_{t}$ value of the gene of interest. The average $\Delta C_{t}$ value for 3 experiments was calculated, for each gene of interest, and the average normalized transcription was calculated as follows: $2(- \text { average } \Delta \mathrm{Ct})^{-1}$. Fold increases of gene transcription, before and after treatment was calculated by dividing the average normalized transcription of each gene in the test sample by the corresponding control. Statistical significance in up- or down-regulation of transcription was determined by Student $T$-test ( 2 -sample, equal variance, 2-tailed distribution), comparing the $\Delta \Delta \mathrm{C}_{\mathrm{t}}\left(\Delta \Delta \mathrm{C}_{\mathrm{t}}=\Delta \mathrm{C}_{\mathrm{t}}\right.$ treated $-\Delta \Delta C_{t}$ control). Significant differences were identified when $\mathrm{P}$ was less than 0.05 .

\section{Analysis of protein interactive networks and statistical analysis}

Functional analysis of interacting proteins was determined using a commercial System Biology package, Ingenuity Pathways Analysis (IPA 8.0) (www.ingenuity. com) following the application protocols.

\section{Statistical analysis}

The statistical significance of differences between groups was determined using the program GraphPad Prism. A $P$ value of $<0.05$ was considered statistically significant. Statistical analysis was performed using one table $T$-test or the unpaired $T$-test. Error bars represent standard error of the mean (S. E.).

\section{Competing interests}

The authors declare that they have no competing interests.

\section{Authors' contributions}

MA analyzed data and wrote the manuscript. MS and WL did experiments. RTC and NLL analyzed data. RGL did experiments, analyzed data and wrote the manuscript. All authors read and approved the final manuscript.

\footnotetext{
Acknowledgements

We thank Dr. Nobuyuki Kato (Okayama University, Japan) for his kind gift of the OR6 replicon cell-line. We thank Christa Osuna-Gutierrez (Beth Israel Deaconess Medical Center) for critical reading of the manuscript. This study was funded by NIH and the Department of Defense (N01 Al30048, N01 Al30049, Al067854 and Al060354-06). We thank Dr. Carmen Plasencia (Acceleromics, Spain) for help with the systems biology approach.
}

\section{Author details}

'Division of Viral Pathogenesis, BIDMC, Boston, MA 02215, USA. ${ }^{2}$ Harvard Medical School, Boston, MA 02215, USA. ${ }^{3}$ Gastrointestinal Unit, Massachusetts General Hospital, Boston, MA 02114, USA
Received: 28 February 2012 Accepted: 27 September 2012

Published: 2 October 2012

\section{References}

1. Naggie S, Sulkowski MS: Management of patients coinfected with HCV and HIV: a close look at the role for direct-acting antivirals. Gastroenterology 2012, 142:1324-1334. e1323.

2. Rockstroh JK: Influence of viral hepatitis on HIV infection. J Hepatol 2006 , 44:S25-S27.

3. Benhamou Y, Bochet M, Di Martino V, Charlotte F, Azria F, Coutellier A, Vidaud M, Bricaire F, Opolon P, Katlama C, Poynard T: Liver fibrosis progression in human immunodeficiency virus and hepatitis $C$ virus coinfected patients. The Multivirc Group. Hepatology 1999, 30:1054-1058.

4. Martin-Carbonero L, Benhamou Y, Puoti M, Berenguer J, Mallolas J, Quereda C, Arizcorreta A, Gonzalez A, Rockstroh J, Asensi V, et al: Incidence and predictors of severe liver fibrosis in human immunodeficiency virusinfected patients with chronic hepatitis C: a European collaborative study. Clin Infect Dis 2004, 38:128-133.

5. Martinez-Sierra C, Arizcorreta A, Diaz F, Roldan R, Martin-Herrera L, PerezGuzman E, Giron-Gonzalez JA: Progression of chronic hepatitis $C$ to liver fibrosis and cirrhosis in patients coinfected with hepatitis $C$ virus and human immunodeficiency virus. Clin Infect Dis 2003, 36:491-498.

6. Bica I, McGovern B, Dhar R, Stone D, McGowan K, Scheib R, Snydman DR: Increasing mortality due to end-stage liver disease in patients with human immunodeficiency virus infection. Clin Infect Dis 2001, 32:492-497.

7. Rosenthal E, Poiree M, Pradier C, Perronne C, Salmon-Ceron D, Geffray L, Myers RP, Morlat P, Pialoux G, Pol S, Cacoub P: Mortality due to hepatitis C-related liver disease in HIV-infected patients in France (Mortavic 2001 study). AIDS 2003, 17:1803-1809.

8. Gebo KA, Diener-West M, Moore RD: Hospitalization rates differ by hepatitis C satus in an urban HIV cohort. J Acquir Immune Defic Syndr 2003, 34:165-173.

9. Gilleece YC, Browne RE, Asboe D, Atkins M, Mandalia S, Bower M, Gazzard $B G$, Nelson MR: Transmission of hepatitis $C$ virus among HIV-positive homosexual men and response to a 24-week course of pegylated interferon and ribavirin. J Acquir Immune Defic Syndr 2005, 40:41-46.

10. Micallef JM, Kaldor JM, Dore GJ: Spontaneous viral clearance following acute hepatitis C infection: a systematic review of longitudinal studies. J Viral Hepat 2006, 13:34-41.

11. Dominguez S, Ghosn J, Valantin MA, Schruniger A, Simon A, Bonnard P, Caumes E, Pialoux G, Benhamou Y, Thibault V, Katlama C: Efficacy of early treatment of acute hepatitis $C$ infection with pegylated interferon and ribavirin in HIV-infected patients. AIDS 2006, 20:1157-1161.

12. Kamal SM, Fouly AE, Kamel RR, Hockenjos B, Al Tawil A, He Q, Khalifa KE, Koziel MJ, El Naggar KM, Rasenack J, Afdhal NH: Peginterferon alfa-2b therapy in acute hepatitis C: impact of onset of therapy on sustained virologic response. Gastroenterology 2006, 130:632-638.

13. Jaeckel E, Cornberg M, Wedemeyer H, Santantonio T, Mayer J, Zankel M, Pastore G, Dietrich M, Trautwein C, Manns MP: Treatment of acute hepatitis C with interferon alfa-2b. N Engl J Med 2001, 345:1452-1457.

14. Nunez M, Lana R, Mendoza JL, Martin-Carbonero L, Soriano V: Risk factors for severe hepatic injury after introduction of highly active antiretroviral therapy. J Acquir Immune Defic Syndr 2001, 27:426-431.

15. Lana R, Nunez M, Mendoza JL, Soriano V: Rate and risk factors of liver toxicity in patients receiving antiretroviral therapy. Med Clin (Barc) 2001, 117:607-610.

16. Sulkowski MS, Thomas DL, Chaisson RE, Moore RD: Hepatotoxicity associated with antiretroviral therapy in adults infected with human immunodeficiency virus and the role of hepatitis $C$ or $B$ virus infection. JAMA 2000, 283:74-80.

17. Mauss S, Valenti W, DePamphilis J, Duff F, Cupelli L, Passe S, Solsky J, Torriani FJ, Dieterich D, Larrey D: Risk factors for hepatic decompensation in patients with HIV/HCV coinfection and liver cirrhosis during interferon-based therapy. AIDS 2004, 18:F21-F25.

18. Bani-Sadr F, Carrat F, Pol S, Hor R, Rosenthal E, Goujard C, Morand P, Lunel-Fabiani F, Salmon-Ceron D, Piroth L, et al: Risk factors for symptomatic mitochondrial toxicity in HIV/hepatitis C virus-coinfected patients during interferon plus ribavirin-based therapy. J Acquir Immune Defic Syndr 2005, 40:47-52.

19. Chung RT, Andersen J, Volberding P, Robbins GK, Liu T, Sherman KE, Peters MG, Koziel MJ, Bhan AK, Alston B, et al: Peginterferon Alfa-2a plus ribavirin 
versus interferon alfa-2a plus ribavirin for chronic hepatitis C in HIVcoinfected persons. N Engl J Med 2004, 351:451-459.

20. Torriani FJ, Ribeiro RM, Gilbert TL, Schrenk UM, Clauson M, Pacheco DM, Perelson AS: Hepatitis $\mathrm{C}$ virus $(\mathrm{HCV})$ and human immunodeficiency virus (HIV) dynamics during HCV treatment in HCV/HIV coinfection. J Infect Dis 2003, 188:1498-1507.

21. Manns MP, McHutchison JG, Gordon SC, Rustgi VK, Shiffman M, Reindollar R, Goodman ZD, Koury K, Ling M, Albrecht JK: Peginterferon alfa-2b plus ribavirin compared with interferon alfa- $2 b$ plus ribavirin for initial treatment of chronic hepatitis C: a randomised trial. Lancet 2001, 358:958-965.

22. Fried MW, Shiffman ML, Reddy KR, Smith C, Marinos G, Goncales FL Jr, Haussinger D, Diago M, Carosi G, Dhumeaux D, et al: Peginterferon alfa-2a plus ribavirin for chronic hepatitis C virus infection. N Engl J Med 2002 347:975-982.

23. Sulkowski MS, Mehta SH, Chaisson RE, Thomas DL, Moore RD: Hepatotoxicity associated with protease inhibitor-based antiretroviral regimens with or without concurrent ritonavir. AIDS 2004, 18:2277-2284.

24. Eron J Jr, Yeni P, Gathe J Jr, Estrada V, DeJesus E, Staszewski S, Lackey P, Katlama C, Young B, Yau L, et al: The KLEAN study of fosamprenavirritonavir versus lopinavir-ritonavir, each in combination with abacavirlamivudine, for initial treatment of HIV infection over 48 weeks: a randomised non-inferiority trial. Lancet 2006, 368:476-482.

25. Miyazaki M, Kato M, Tanaka M, Tanaka K, Takao S, Kohjima M, Ito T, Enjoji M, Nakamuta M, Kotoh K, Takayanagi R: Antithrombin III injection via the portal vein suppresses liver damage. World J Gastroenterol, 18:1884-1891.

26. Opal SM, Esmon CT: Bench-to-bedside review: functional relationships between coagulation and the innate immune response and their respective roles in the pathogenesis of sepsis. Crit Care 2003, 7:23-38.

27. Congote LF: The C-terminal 26-residue peptide of serpin $A 1$ is an inhibitor of HIV-1. Biochem Biophys Res Commun 2006, 343:617-622.

28. Congote LF: Serpin A1 and CD91 as host instruments against HIV-1 infection: are extracellular antiviral peptides acting as intracellular messengers? Virus Res 2007, 125:119-134

29. Shugars DC, Sauls DL, Weinberg JB: Secretory leukocyte protease inhibitor blocks infectivity of primary monocytes and mononuclear cells with both monocytotropic and lymphocytotropic strains of human immunodeficiency virus type I. Oral Dis 1997, 3(Suppl 1):S70-S72.

30. McNeely TB, Shugars DC, Rosendahl M, Tucker C, Eisenberg SP, Wahl SM: Inhibition of human immunodeficiency virus type 1 infectivity by secretory leukocyte protease inhibitor occurs prior to viral reverse transcription. Blood 1997, 90:1141-1149.

31. MCNeely TB, Dealy M, Dripps DJ, Orenstein JM, Eisenberg SP, Wahl SM: Secretory leukocyte protease inhibitor: a human saliva protein exhibiting anti-human immunodeficiency virus 1 activity in vitro. J Clin Invest 1995, 96:456-464

32. Shapiro L, Pott GB, Ralston AH: Alpha-1-antitrypsin inhibits human immunodeficiency virus type 1. FASEB J 2001, 15:115-122.

33. Elmaleh DR, Brown NV, Geiben-Lynn R: Anti-viral activity of human antithrombin III. Int J Mol Med 2005, 16:191-200.

34. Geiben-Lynn R, Brown N, Walker BD, Luster AD: Purification of a modified form of bovine antithrombin III as an HIV-1 CD8+ T-cell antiviral factor. J Biol Chem 2002, 277:42352-42357.

35. Agnello V, Abel G, Elfahal M, Knight GB, Zhang QX: Hepatitis C virus and other flaviviridae viruses enter cells via low density lipoprotein receptor. Proc Natl Acad Sci USA 1999, 96:12766-12771.

36. Lillis AP, Van Duyn LB, Murphy-Ullrich JE, Strickland DK: LDL receptorrelated protein 1: unique tissue-specific functions revealed by selective gene knockout studies. Physiol Rev 2008, 88:887-918.

37. Ikeda M, Abe K, Dansako H, Nakamura T, Naka K, Kato N: Efficient replication of a full-length hepatitis $C$ virus genome, strain $O$, in cell culture, and development of a luciferase reporter system. Biochem Biophys Res Commun 2005, 329:1350-1359.

38. Alter MJ, Kruszon-Moran D, Nainan OV, McQuillan GM, Gao F, Moyer LA, Kaslow RA, Margolis HS: The prevalence of hepatitis $C$ virus infection in the United States, 1988 through 1994. N Engl J Med 1999, 341:556-562.

39. Blatt LM, Mutchnick MG, Tong MJ, Klion FM, Lebovics E, Freilich B, Bach N, Smith C, Herrera J, Tobias $H$, et al: Assessment of hepatitis $C$ virus RNA and genotype from 6807 patients with chronic hepatitis $C$ in the United States. J Viral Hepat 2000, 7:196-202.
40. Whitney JB, Asmal M, Geiben-Lynn R: Serpin Induced Antiviral Activity of Prostaglandin Synthetase-2 against HIV-1 Replication. PLoS One 2011, 6:e18589.

41. Ikeda M, Abe K, Yamada M, Dansako H, Naka K, Kato N: Different anti-HCV profiles of statins and their potential for combination therapy with interferon. Hepatology 2006, 44:117-125.

42. Hassan M, Selimovic D, Ghozlan H, Abdel-kader O: Hepatitis C virus core protein triggers hepatic angiogenesis by a mechanism including multiple pathways. Hepatology 2009, 49:1469-1482.

43. Miller K, McArdle S, Gale MJ Jr, Geller DA, Tenoeve B, Hiscott J, Gretch DR, Polyak SJ: Effects of the hepatitis $C$ virus core protein on innate cellular defense pathways. J Interferon Cytokine Res 2004, 24:391-402.

44. Matsuzaki K, Murata M, Yoshida K, Sekimoto G, Uemura Y, Sakaida N, Kaibori M, Kamiyama Y, Nishizawa M, Fujisawa J, et al: Chronic inflammation associated with hepatitis $C$ virus infection perturbs hepatic transforming growth factor beta signaling, promoting cirrhosis and hepatocellular carcinoma. Hepatology 2007, 46:48-57.

45. Wohnsland A, Hofmann WP, Sarrazin C: Viral determinants of resistance to treatment in patients with hepatitis C. Clin Microbiol Rev 2007, 20:23-38.

46. Meurs EF, Breiman A: The interferon inducing pathways and the hepatitis C virus. World J Gastroenterol 2007, 13:2446-2454.

47. Girard S, Vossman E, Misek DE, Podevin P, Hanash S, Brechot C, Beretta L: Hepatitis $C$ virus NS5A-regulated gene expression and signaling revealed via microarray and comparative promoter analyses. Hepatology 2004, 40:708-718.

48. Dou J, Liu P, Wang J, Zhang X: Effect of hepatitis $C$ virus core shadow protein expressed in human hepatoma cell line on human gene expression profiles. J Gastroenterol Hepatol 2006, 21:1794-1800.

49. Park $C Y$, Jun HJ, Wakita T, Cheong JH, Hwang SB: Hepatitis C virus nonstructural $4 \mathrm{~B}$ protein modulates sterol regulatory element-binding protein signaling via the AKT pathway. J Biol Chem 2009, 284:9237-9246.

50. Saito I, Miyamura T, Ohbayashi A, Harada H, Katayama T, Kikuchi S, Watanabe $Y$, Koi S, Onji M, Ohta Y, et al: Hepatitis C virus infection is associated with the development of hepatocellular carcinoma. Proc Nat/ Acad Sci USA 1990, 87:6547-6549.

51. Machida K, Tsukamoto H, Liu JC, Han YP, Govindarajan S, Lai MM, Akira S, Ou JH: c-Jun mediates hepatitis $C$ virus hepatocarcinogenesis through signal transducer and activator of transcription 3 and nitric oxidedependent impairment of oxidative DNA repair. Hepatology, 52:480-492.

52. Farinati F, Cardin R, Bortolami M, Guido M, Rugge M: Oxidative damage, pro-inflammatory cytokines, TGF-alpha and c-myc in chronic HCV-related hepatitis and cirrhosis. World J Gastroenterol 2006, 12:2065-2069.

53. Chung RT, Gale M Jr, Polyak SJ, Lemon SM, Liang TJ, Hoofnagle JH: Mechanisms of action of interferon and ribavirin in chronic hepatitis C: Summary of a workshop. Hepatology 2008, 47:306-320.

54. Castet V, Fournier C, Soulier A, Brillet R, Coste J, Larrey D, Dhumeaux D, Maurel P, Pawlotsky JM: Alpha interferon inhibits hepatitis $C$ virus replication in primary human hepatocytes infected in vitro. J Virol 2002, 76:8189-8199.

55. Sheikh SMR, Viunytska LV: Anithrombin III as a criteria marker in chronic liver disease. The Internet Journal of Laboratory Medicine 2009, 3.

56. Pizzo SV: Serpin receptor 1: a hepatic receptor that mediates the clearance of antithrombin III-proteinase complexes. Am J Med 1989, 87:10S-14S.

57. Tanabe Y, Sakamoto N, Enomoto N, Kurosaki M, Ueda E, Maekawa S, Yamashiro T, Nakagawa M, Chen CH, Kanazawa N, et al: Synergistic inhibition of intracellular hepatitis $C$ virus replication by combination of ribavirin and interferon- alpha. J Infect Dis 2004, 189:1129-1139.

58. Hassan M, Ghozlan H, Abdel-Kader O: Activation of c-Jun NH2-terminal kinase (JNK) signaling pathway is essential for the stimulation of hepatitis $\mathrm{C}$ virus (HCV) non-structural protein 3 (NS3)-mediated cell growth. Virology 2005, 333:324-336.

59. Cui J, Dong BW, Liang P, Yu XL, Yu DJ: Construction and clinical significance of a predictive system for prognosis of hepatocellular carcinoma. World J Gastroenterol 2005, 11:3027-3033.

60. Chan SW, Egan PA: Hepatitis $C$ virus envelope proteins regulate $\mathrm{CHOP}$ via induction of the unfolded protein response. FASEB J 2005, 19:1510-1512.

61. Nishitoh H, Matsuzawa A, Tobiume K, Saegusa K, Takeda K, Inoue K, Hori S, Kakizuka A, Ichijo H: ASK1 is essential for endoplasmic reticulum stressinduced neuronal cell death triggered by expanded polyglutamine repeats. Genes Dev 2002, 16:1345-1355. 
62. Babitt JL, Huang FW, Wrighting DM, Xia Y, Sidis Y, Samad TA, Campagna JA, Chung RT, Schneyer AL, Woolf CJ, et al: Bone morphogenetic protein signaling by hemojuvelin regulates hepcidin expression. Nat Genet 2006, 38:531-539.

63. Tai AW, Benita Y, Peng LF, Kim SS, Sakamoto N, Xavier RJ, Chung RT: A functional genomic screen identifies cellular cofactors of hepatitis $C$ virus replication. Cell Host Microbe 2009, 5:298-307.

64. Aoki CA, Rossaro L, Ramsamooj R, Brandhagen D, Burritt MF, Bowlus CL: Liver hepcidin mRNA correlates with iron stores, but not inflammation, in patients with chronic hepatitis C. J Clin Gastroenterol 2005, 39:71-74.

65. Nemeth E, Rivera S, Gabayan V, Keller C, Taudorf S, Pedersen BK, Ganz T: IL-6 mediates hypoferremia of inflammation by inducing the synthesis of the iron regulatory hormone hepcidin. J Clin Invest 2004, 113:1271-1276.

66. Schmitz KJ, Wohlschlaeger J, Lang H, Sotiropoulos GC, Malago M, Steveling K, Reis H, Cicinnati VR, Schmid KW, Baba HA: Activation of the ERK and AKT signalling pathway predicts poor prognosis in hepatocellular carcinoma and ERK activation in cancer tissue is associated with hepatitis C virus infection. J Hepatol 2008, 48:83-90.

67. Shrivastava A, Manna SK, Ray R, Aggarwal BB: Ectopic expression of hepatitis $C$ virus core protein differentially regulates nuclear transcription factors. J Virol 1998, 72:9722-9728.

68. Tan SL, Nakao H, He Y, Vijaysri S, Neddermann P, Jacobs BL, Mayer BJ, Katze MG: NS5A, a nonstructural protein of hepatitis $C$ virus, binds growth factor receptor-bound protein 2 adaptor protein in a Src homology 3 domain/ligand-dependent manner and perturbs mitogenic signaling. Proc Natl Acad Sci USA 1999, 96:5533-5538.

69. Georgopoulou U, Caravokiri K, Mavromara P: Suppression of the ERK1/2 signaling pathway from HCV NS5A protein expressed by herpes simplex recombinant viruses. Arch Virol 2003, 148:237-251.

doi:10.1186/1743-422X-9-226

Cite this article as: Asmal et al:: Inhibition of HCV by the serpin antithrombin III. Virology Journal 2012 9:226.

\section{Submit your next manuscript to BioMed Central and take full advantage of:}

- Convenient online submission

- Thorough peer review

- No space constraints or color figure charges

- Immediate publication on acceptance

- Inclusion in PubMed, CAS, Scopus and Google Scholar

- Research which is freely available for redistribution 